\title{
LLNL UCG Commercialization "Sweet Spot" Analysis
}

Julio Friedmann, Noah Goldstein, Lee Neher, Lynn Wilder

February 6, 2008 
This document was prepared as an account of work sponsored by an agency of the United States government. Neither the United States government nor Lawrence Livermore National Security, LLC, nor any of their employees makes any warranty, expressed or implied, or assumes any legal liability or responsibility for the accuracy, completeness, or usefulness of any information, apparatus, product, or process disclosed, or represents that its use would not infringe privately owned rights. Reference herein to any specific commercial product, process, or service by trade name, trademark, manufacturer, or otherwise does not necessarily constitute or imply its endorsement, recommendation, or favoring by the United States government or Lawrence Livermore National Security, LLC. The views and opinions of authors expressed herein do not necessarily state or reflect those of the United States government or Lawrence Livermore National Security, LLC, and shall not be used for advertising or product endorsement purposes.

This work performed under the auspices of the U.S. Department of Energy by Lawrence Livermore National Laboratory under Contract DE-AC52-07NA27344. 


\title{
LLNL UCG Commercialization "Sweet Spot” Analysis
}

Dr. S. Julio Friedmann, Carbon Management Program Leader

\author{
Carbon Management Program Leader (PI) \\ Energy \& Environmental Directorate \\ Lawrence Livermore National Laboratory \\ 7000 East Ave Livermore, CA 94550-9234 \\ friedmann2@1lnl.gov \\ 1-925-423-0585
}

With

Dr. Noah Goldstein, Economic / Social Analysis

Lee Neher and Lynn Wilder, GIS/Geomodeling team

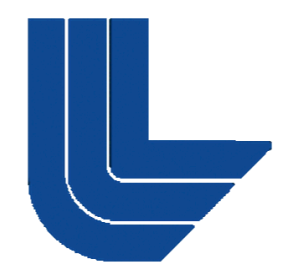

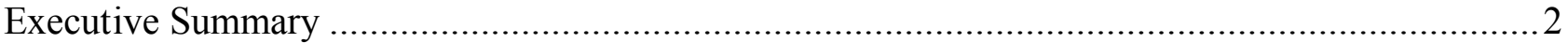

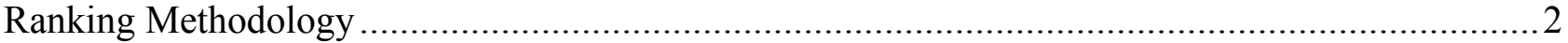

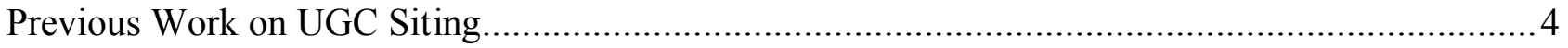

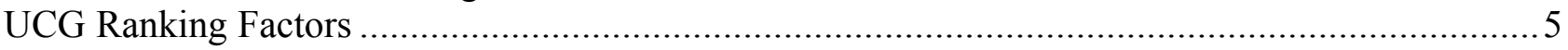

The Geologic Resource Assumptions and Methodology ……................................................5

The Infrastructure Resource Assumptions and Methodology ....................................................6

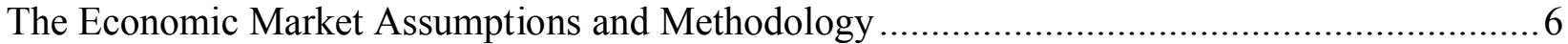

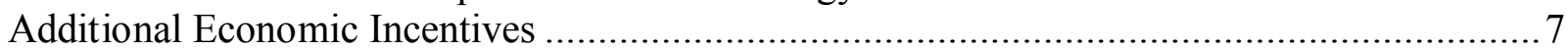

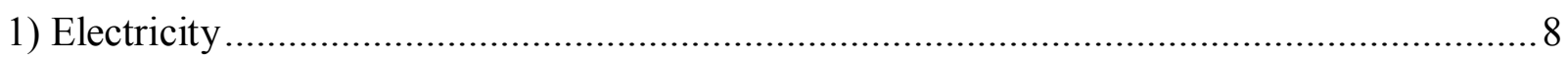

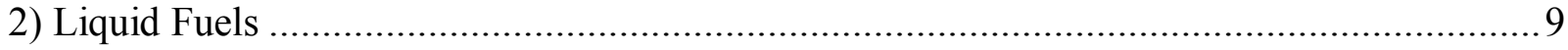

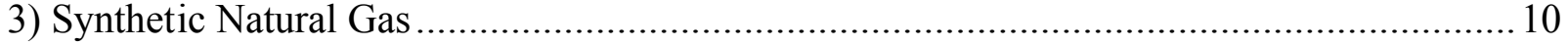

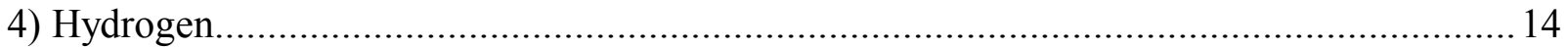

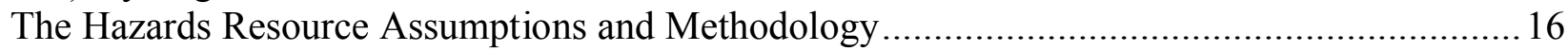

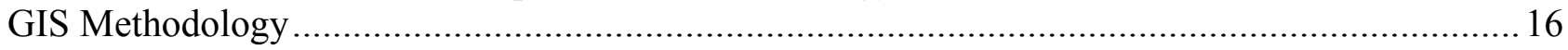

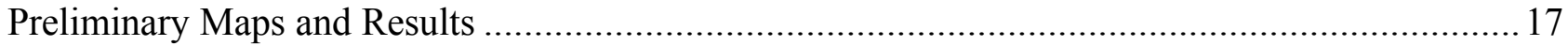

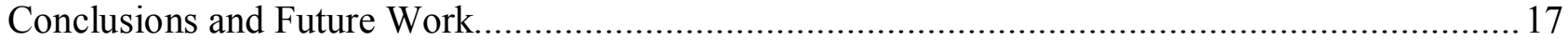

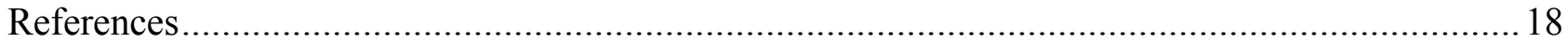

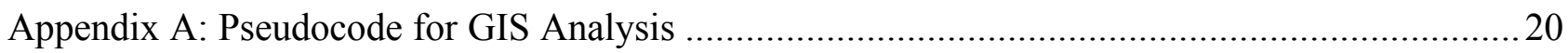

Appendix B: Dataset Sources and Coarse Metadata ....................................................................2 
Noah - V14 - Jan 31, 2008

TO DO:

Other work text

Edit

\section{Executive Summary}

Underground Coal Gasification (UCG) is a promising endeavor that utilizes coal reserves in a manner that can provide a variety of energy products, including Electricity and Liquid Fuels, with low or zero carbon emissions. This work comprises a preliminary site suitability analysis for UCG in the US, focusing on regions that both show the best potential for UCG, and for which data is available. We view this work as a "first pass" of site suitability for UCG. In order to comprise a more complete analysis, stakeholder feedback is needed to capture the logic and views of the practical or applied site suitability. In this first pass (Stage I), we focus on the states of Illinois, Wyoming, and Texas. Since we were unable to get key geological data for Texas, we were only able to complete analysis for Illinois and Wyoming. We are currently working with the USGS to get the data and perform the analysis. In this document, we present the framework for the site suitability methodology, the pseudocode used in generating suitability maps, the maps themselves, and finally, a catalog of our data sources.

In our initial study, we have successfully applied the site suitability ranking to each state. Preliminary analysis suggests that........... Subsequent work must include the following: complete site suitability for Illinois, Wyoming and Texas, analysis of all of North America, incorporation of peer-reviewed verification of methodology and results, and most significantly, the incorporation of guidelines from BP on their commercial decision-making logic, and the encapsulation of their preferences of geological and hazard decision rules.

\section{Ranking Methodology}

The goal of this project is to rank geographic regions to identify "Sweet Spots" where Underground Coal Gasification (UCG) is feasible both technically and economically. This is an example of Multi-Attribute Utility Analysis (MAUA) (Huber, 1974), where "models are designed to obtain the utility of items or alternatives that have more than one valued property and therefore must be evaluated on more than one criterion" Huber, 1974 p. 1393. Given unlimited time and resources, the MAUA would be tailored precisely to the users needs. Given the limited constraints on this project, we will develop a methodology for ranking UCG, using a case study (Stage I) as a proof-ofconcept.

This analysis will not explicitly focus on Risk-based Decision-Making (RBDM), common in many siting analysis (e.g., McMillen, et al., 2001), as this siting study goes beyond environmental and hazard risk assessments and incorporates economic and infrastructure components. Additionally, RBDM frequently does a specific site analysis, as opposed to a broad-scale, large domain analysis, as is done in this study. Future analysis will surely utilize RBDM, and the framework presented here will be able to incorporate those results. 
The dimensions of concern for siting an energy facility, according to Keeney (1980) are:
1. The Environment
2. Economics
3. Socioeconomics
4. Health and Safety
5. Public Attitudes

We will be evaluating all of these concerns to some degree, yet not in this distinct taxonomy. For this study, we will be classifying the major factors as:
1) Geologic Resource
2) The Infrastructure
3) The Market
4) The Hazards

The major factors above are in essence proxies for a UCG market, namely; Supply (Geologic Resource), Demand (Market), distribution of goods (Infrastructure), and socioeconomic and other constraints (Hazards). As this suitability model is not an explicit UCG economics model, some components will mach up more closely with their market components, while others are more of an allusion to their real function in a market.

The core Methodology of this project is to evaluate diverse geospatial and economic data for their feasibility for UCG. The procedure used in this preliminary analysis (Stage I) is essentially a site selection process, where specific locations are located and ranked in a large region (i.e. States). In subsequent analysis (Stage II), a complete Decision Analytical approach would be appropriate to compare more explicitly the locations found to be highly feasible in Stage I. Due to the variability in the needs and economic benefits for each UCG product $(\mathrm{H} 2$, Synthetic Natural Gas, Liquid fuels, Electricity), each product will be evaluated separately, and then combined to form a universal site suitability. This analysis is more focused on the supply and delivery components of UCG, relative to the demand side UCG suitability.

Overall Flow of Actions:

1) Identify geographic units of analysis

2) Determine characteristics to be included in ranked scoring system

3) Evaluate geospatial and economic data into utility function

4) Analyze ranking

5) Summarize and present results.

For this preliminary analysis, each "layer", in a GIS sense, will represent a continuous suitability surface. The layers' feasibility will be represented by ordinal values from 0 (completely unsuitable, such as a lake) to 5 (ideal for UCG). Each group of layers, representing similar suitability topics (Economics, geology, product demand, etc...), will be integrated (in this case summed) to determine the topic feasibility. These summed layer feasibilities will be united to form a single continuous feasibility surface for the study region (Figure 1). The benefit of using a tiered summation procedure is the ability to evaluate the feasibility with respect to each individual concern. 


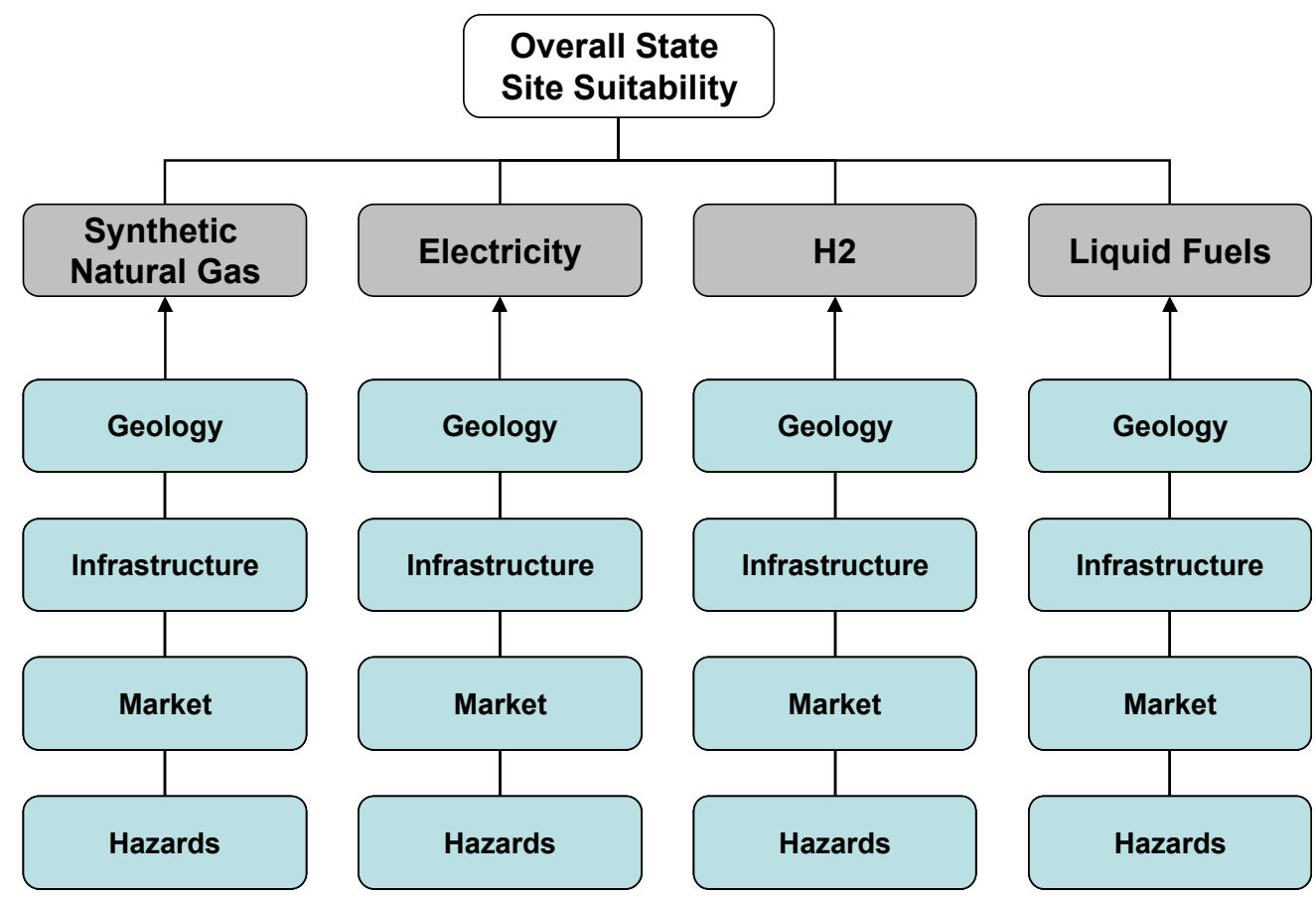

Figure 1 - Site Suitability Methodology

This preliminary study (Phase I) will use assumed ranking values and cutoff points for layers in each topic area. Future extensions of this work (Phase II) will incorporate the decision-making process and corporate goals into the ranking. This would then afford the utility of alternative ranking systems, including Fuzzy Logic (as per Zadeh) or an asymmetrical points system.

\section{Previous Work on UGC Siting}

The LLNL "Best Practices" report outlines a number of requirements for UGC Siting (Table 1):

\begin{tabular}{|l|l|l|}
\hline \multicolumn{3}{|c|}{ Minimal requirements for UCG siting and operation } \\
\hline & Minimal Requirements & Additional Notes \\
\hline Coal Rank & $\begin{array}{l}\text { Must be bituminous or lower } \\
\text { rank }\end{array}$ & $\begin{array}{l}\text { May have difficulties with } \\
\text { high ranked bituminous coals }\end{array}$ \\
\hline $\begin{array}{l}\text { Coal Seam } \\
\text { Thickness }\end{array}$ & $>0.5 \mathrm{~m}$ thick & $\begin{array}{l}\text { Best performance above } 1.5 \mathrm{~m} \\
\text { thickness }\end{array}$ \\
\hline Seam Depth & $12 \mathrm{~m}$ & Preferred deeper than $150 \mathrm{~m}$ \\
\hline Site Access & $\begin{array}{l}\text { Must have broad drilling and } \\
\text { monitoring access }\end{array}$ & \\
\hline Water Table & Must be below water table & $\begin{array}{l}\text { Should not be source of local } \\
\text { drinking water }\end{array}$ \\
\hline Water Composition & $\begin{array}{l}\text { Best if not potable water i.e. } \\
\text { TDS }>1,000 \text { ppm }\end{array}$ \\
\hline
\end{tabular}

Table 1. From Burton, et al, (2006) "Best Practices of UCG"

Potential sites must meet minimal requirements (Table 1);

- Stratigraphic and structural characterization is needed to satisfy information requirements for rapid qualitative risk protocols; 
- Preferred consideration should be given for sites deeper than $200 \mathrm{~m}$;

- Preferred consideration should be given for sites with strong or rigid overlying strata;

- Downgraded consideration should be given to sites where the coal seams or surrounding strata act as aquifers that may be USDWS;

- Downgraded consideration should be given to heavily deformed structures or steeply dipping seams.

Pages 90-91, Burton, et al, 2006 "Best Practices of UCG"

\section{UCG Ranking Factors}

We used the following geospatial components to rank the regions for high UCG suitability:

1. The Geologic Resource - both resource for coal and sequestration

a. Thickness of seam

b. Density estimation of available reserves

c. Coal Rank and energy content

d. Overburden characteristics

2. The Infrastructure

a. Location of current pipelines, substations, etc...

b. Distance to Infrastructure and methodology (pipeline, trucking, etc...)

3. The Market

a. Industry locations

b. Price and volume demanded for products

c. Land Ownership*

d. Sequestration Potential

e. Enhanced Oil Recovery Potential

4. The Hazards - both real and perceived

a. Local aquifer(s), current contamination level of each *

b. The vertical proximity of hydrostratigraphic zones, to each other and coal seams *

c. Current surface land-use

d. Presence of mines, faults and wells

e. Stratigraphic vulnerability *

* - indicates Hazard components to be included in Stage II

The factors tagged for incorporation in Stage II we done so either for data availability or for lack of stakeholder input. For example, Land Ownership, either Federal, State, or Private, is a significant component of Site Suitability. Yet without understanding how BP ranks these different types of ownership, we have chosen to presently exclude it from the analysis.

What follows is a description of the methodology of the ranking factors, with respect to data and approach. In Appendix B the pseudocode for each factor is presented.

\section{The Geologic Resource Assumptions and Methodology}

The goal of the Geologic Resource ranking is to identify regions that have characteristics of possessing a rich coal substrate to utilize for UCG. Due to the variety of proprietary rules, regulations, and government activity, both at the Federal and State level, mapping the coal resource in each State is not a consistent process. Currently we have obtained USGS Coal Reserve maps for 
Illinois and Wyoming, but not for Texas. These maps contain data on a variety of geologic features including:

- Thickness of seam

- Density estimation of available reserves

- Coal Rank and energy content

- Overburden characteristics

The extent of the USGS data is different for Illinois and Wyoming. The USGS provide a fairly complete coverage of the major resource areas in Illinois. In Wyoming however, the data are limited to the major Coal resource areas, and not beyond them. This is partly a function of the data collection abilities of the USGS. In Stage II we hope to incorporate the USGS data for Texas, but more significantly, well data ("unit calls") from the entire state to expand the data richness beyind the limited USGS study areas.

\section{The Infrastructure Resource Assumptions and Methodology}

Each UCG product has its own method of distribution. We capture these differences by evaluating the Infrastructure for each product independently. We define Infrastructure as equipment needed to get the products to market. Each product's Infrastructure layer is described as follows:

1) Electricity

The infrastructure used for moving electricity is the location of Electric Substations. While the presence of transmission lines is an indication of potential right-of-ways, tapping into those lines is not an easy task. The ability to tap into the electricity grid at substations is significantly easier.

2) Liquid Fuels

There are a number of Liquid Fuels that can be produced from UCG. Some products (such as Jet Fuel) are currently shipped by pipeline. For a nascent or small scale operation, trucking those products to market is a more feasible option. We use the location of major highways (interstates) as an indication of the presence or proximity of infrastructure for suitability.

3) Natural Gas

Natural Gas (or Synthetic Natural Gas) can move both by truck or pipeline. For this study, we use the current pipeline infrastructure, specifically the proximity of pipelines used for Natural Gas as a factor of suitability.

4) Hydrogen

In the next 30 years, we could very likely see the development of a Hydrogen economy, with Hydrogen powering many of the nation's cars. Currently Hydrogen is used as a ram material for Fertilizer and other industrial processes. There are large unknowns about the details of this economy, namely the methodology of Hydrogen distribution or where in the US Hydrogen will be first rolled out. Due to this uncertainty, we account for the potential infrastructure of Hydrogen in two ways. First is through trucking, which has a low capital investment and is highly flexible. The second manner is the pipeline infrastructure, as new Hydrogen pipelines may be able to use the same right-of-ways as current pipelines (Johnson, 2005).

\section{The Economic Market Assumptions and Methodology}


As a part of the site suitability analysis, the market outlook of each of the four main UCG products (Electricity, Liquid Fuels, Synthetic Natural Gas, and Hydrogen) was generated. We identified three components of this outlook; the location of the access to the demand centers (and not necessarily the demand centers themselves), the relative inter-state economic rank of each market (if applicable), and an "Additional Economic Incentives" components that includes Sequestration and Enhanced Oil Recovery potential. Each UCG product has an independent geospatial "market access layer" and an independent economic rank assessment, if applicable. The "Additional Economic Incentives" layer is independent of product and calculated on a state-wide basis.

Due to the long startup time of large infrastructure projects, we will be using economic forecasts for the year 2013 and 2028, or 5 and 20 years out. For Stage I, we will be focusing on the Residential and Industrial sectors. In Stage II, more specific demand markets can be assessed.

A description of the "Additional Economic Incentives" layer, followed by the details of each market and its forecasted relative size is presented in the following section.

\section{Additional Economic Incentives}

In order to account for non-product-specific economic incentives, the sequestration potential and the potential for using Enhanced Oil recovery (EOR) was mapped and ranked.

In the absence of a peer-reviewed map of national sequestration potential, we used the following map as a placeholder, until better data becomes available (Figure 2).

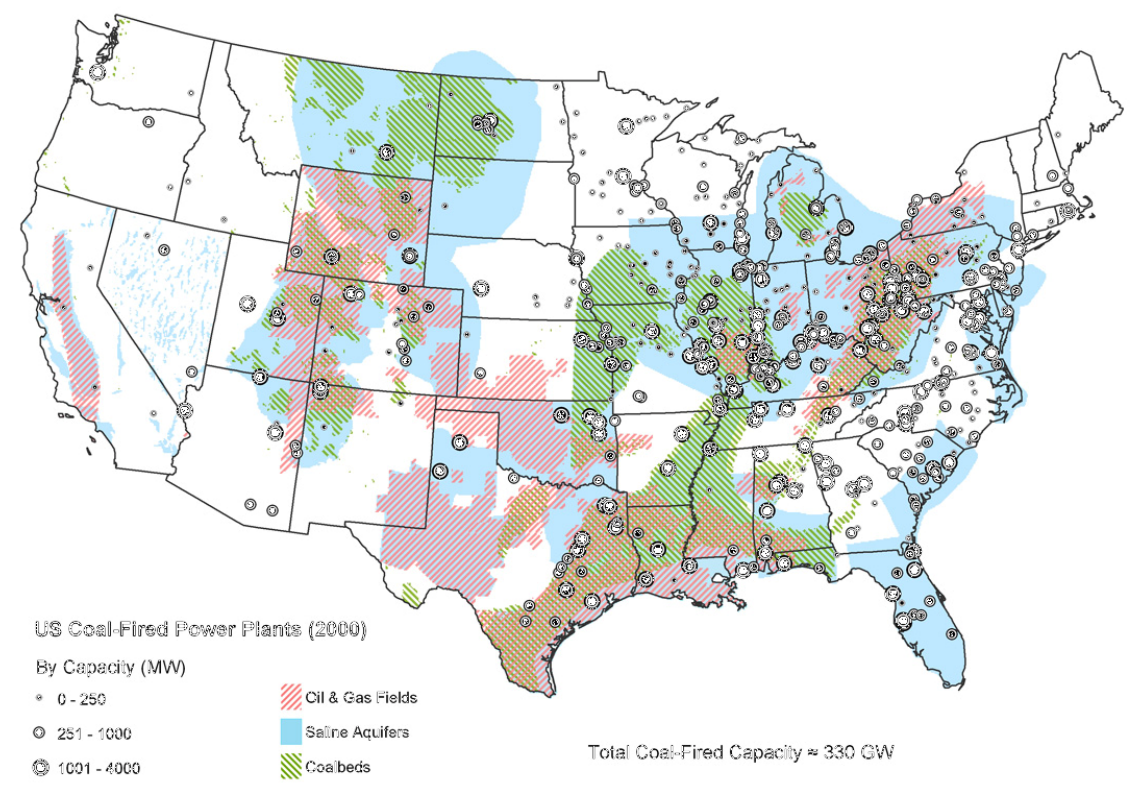

Figure 2 - National Carbon Sequestration Potential. Source: Katzer (2007), p.109

In the Stage I analysis, the presence or absence of any geologic formation with sequestration is promoted. It should be re-stated that this method is admittedly coarse and is in need of refinement. 
We incorporated Enhanced Oil Recovery into the site suitability analysis as it can improve the economic outlook of a project. EOR is the process of injecting a gas (in this case $\mathrm{CO}_{2}$ ) into existing oil reservoirs, increasing the pressure and in turn the effectiveness of oil withdrawal. EOR extends the life of oil fields, allowing the secondary or tertiary recovery of crude from inefficient wells.

\section{1) Electricity}

Coal is widely used for electricity generation worldwide. UCG provides a novel method of electricity generation in a clean, low-carbon manner. Once generated, electricity can tap into the current infrastructure, or necessitate new power lines and transformers being built. For this study, we used the total forecasted demand for all sectors and the forecasted price estimates from Coalgenerated electricity price from the Energy Information Administration (EIA). The current and forecasted congestion issues in the electrical grid are not be included in the analysis at this point.

To forecast state-wide electricity demand in each of the States of interest for 5 and 20 years out, we would ideally know each State's contribution to the National Electricity Grid, specifically its generation proportion to its local National Electricity Reliability Council (NERC) Interconnections, as well as local demand. .

From the EIA Electric Power Annual 2006 - State Data Tables (EIA 2007b), the proportion of each state's electricity market is available. The percentages of size of electricity market will be used to determine the size of the future energy market for each state (Table 3 ).

\begin{tabular}{|l|c|}
\hline State & $\begin{array}{c}\text { Percent of entire 2006 } \\
\text { US Total Electricity Market }\end{array}$ \\
\hline Illinois & 3.88 \\
\hline Texas & 9.34 \\
\hline Wyoming & 0.41 \\
\hline
\end{tabular}

Table 3. Proportion of US Electricity Market in each state. Source: EIA 2007b

Size of Future Market:

For the size and valuation of the future energy market, we use the supply and demand forecasts for electricity derived from Steam Coal, as this closely resembles the UGC process. These were obtained from EIA's Annual Energy Outlook (DOE/EIA 2007) (Table 4):

\begin{tabular}{|c|c|c|c|c|}
\hline & \multicolumn{2}{|c|}{$\begin{array}{c}\text { Consumed (Demand) } \\
\text { (quadrillion Btu) }\end{array}$} & \multicolumn{2}{c|}{ Price } \\
(2006 dollars per million Btu)
\end{tabular}

Table 4. Forecasted Electricity Generation from Coal

To calculate the size of the market, multiply the Percentages in Table 5 by the demand in the above table by the price, for each respective market. The ranking in each grid-based Unit of Analysis (UOA) is presented as well.

\begin{tabular}{|c|c|c|c|}
\hline & \multicolumn{2}{|c|}{$\begin{array}{c}\text { Size of Electricity Market (relative to } \\
\text { entire US) }\end{array}$} & SBillion) \\
\hline State & $\mathbf{2 0 1 3}$ & $\mathbf{2 0 2 8}$ & $\mathbf{2 0 1 3} \mathbf{2 0 2 8}$ \\
\hline Illinois & 1.48 & 1.92 & $\mathbf{4}$ \\
\hline Texas & 3.56 & 4.63 & $\mathbf{5}$ \\
\hline
\end{tabular}




\begin{tabular}{|l|c|c|c|}
\hline Wyoming & 0.16 & 0.20 & $\mathbf{3}$ \\
\hline
\end{tabular}

\section{Product: Electricity}

Market: Total Electricity Demand, by State

Future Prices: Coal to Electricity prices

Distribution Method of Interest: Power line infrastructure

\section{2) Liquid Fuels}

The UCG process can produce a variety of Fischer-Tropsch products. This study will focus on Jet Fuel and Diesel, as there is an infrastructure in place for these products and future consumption has been forecasted by EIA. Other Liquid Fuel products can be incorporated in Stage II.

\section{Jet Fuel}

For the purposes of this analysis, we assume that Jet Fuel is sold to two separate markets; Commercial Aviation and the US Military. The different markets of the different "flavors" of Jet Fuel can be incorporated in Stage II. Under these assumptions, Jet Fuel is a fungible commodity, that is, once it gets to a major highway, it can be transported and sold at the closest airport. To this end the market for Jet Fuel can be viewed as a national market. A viable method of assessing local site suitability for the location of a UCG with respect to Jet Fuel is the location of airports. The logic for this suitability is: closer the airports, the better the local market. While Jet Fuels move both via pipeline and trucks, we assume for the short-term, the products would move via trucks.

Due to the paramount importance of Jet Fuel to military customers, we weight the proximity of military bases differently by "relaxing" the distance functions (see Appendix A).

Summary suitability assessment for Jet Fuel:

Product: Jet Fuel

Market: Proximity to airports (Commercial and Military)

Distribution Method of Interest: Trucking

\section{Diesel}

For this study, we view the local Diesel market as having two components; Trucking, and Railroads. While Diesel, like many other fuels, can be transported long distances for sale, we assume that the local market (as opposed to the national market) will dominate. To this end, we calculate the current proportion of the national Diesel market is consumed in each state, and assume that this will continue into the future. Proportional (State-level) sizes of Diesel market were drawn from the "State Energy Consumption, Price, and Expenditure Estimates" (SEDS) report, using 2005 numbers (EIA 2007c) (Table 6).

\begin{tabular}{|c|c|}
\hline State & Percent of entire 2005 US Diesel Market \\
\hline Illinois & 3.20 \\
\hline Texas & 8.51 \\
\hline Wyoming & .94 \\
\hline
\end{tabular}

Table 6. Proportion of US Diesel Market in each State. 
For the size and valuation of the future energy market, we use the supply and demand forecasts for Diesel. These were obtained from EIA's Annual Energy Outlook (DOE/EIA 2007) (Table 7):

\begin{tabular}{|c|c|c|c|c|}
\hline & \multicolumn{2}{|c|}{$\begin{array}{c}\text { Consumed (Demand) } \\
\text { (quadrillion Btu) }\end{array}$} & \multicolumn{2}{c|}{ (2006 dollars per million Btu) } \\
\hline & 2013 & 2028 & 2013 & 2028 \\
\hline Diesel (Distillate Fuel Oil) & 6.83 & 8.63 & 17.76 & 18.80 \\
\hline
\end{tabular}

Table 7. Volume of Diesel consumed and Diesel price. Note: prices include Federal and State taxes, which are subject to change.

To calculate the size of the market, we multiplied the percentages in Table 8 by the demand in the above table by the price, for each respective market.

\begin{tabular}{|c|c|c|}
\hline & \multicolumn{2}{|c|}{$\begin{array}{c}\text { Size of Local Diesel Market (relative to } \\
\text { entire US) (\$Billion) }\end{array}$} \\
\hline State & 2013 & 2028 \\
\hline Illinois & 3.88 & 5.19 \\
\hline Texas & 10.32 & 13.81 \\
\hline Wyoming & 1.14 & 1.53 \\
\hline
\end{tabular}

Table 8. Size of State Diesel markets

The size of the market of Diesel fuels were then translated into relative rankings for the geospatial analysis (Table 9).

\begin{tabular}{|c|c|c|c|}
\hline & \multicolumn{2}{|c|}{$\begin{array}{c}\text { Size of Local Diesel Market } \\
\text { (relative to entire US) (\$Billion) }\end{array}$} & $\begin{array}{c}\text { Statewide UOA } \\
\text { Ranking }\end{array}$ \\
\hline State & $\mathbf{2 0 1 3}$ & $\mathbf{2 0 2 8}$ & $\mathbf{2 0 1 3} \mathbf{2 0 2 8}$ \\
\hline Illinois & 3.88 & 5.19 & $\mathbf{4}$ \\
\hline Texas & 10.32 & 13.81 & $\mathbf{5}$ \\
\hline Wyoming & 1.14 & 1.53 & $\mathbf{3}$ \\
\hline
\end{tabular}

Table 9. Size of Diesel market in dollars and suitability ranking

These ranking are used in concert with distance measurements to gas stations and railroad yards

Product: Diesel

Market: Diesel Demand, by State

Future Prices: Diesel Prices by State

Distribution Method of Interest: Trucking; proximity to Highways, Railroad Yards

\section{3) Synthetic Natural Gas}

Synthetic Natural Gas can augment the current Natural Gas supply. According to EIA's Natural Gas Navigator, (EIA 2007a), the utility of Natural Gas in each States is varied (Table 10).

\begin{tabular}{|l|c|c|c|c|c|}
\hline State & $\begin{array}{c}\text { Natural Gas } \\
\text { \% of Total } \\
\text { US } \\
\text { Residential } \\
\text { Deliveries } \\
\mathbf{( \% )}\end{array}$ & $\begin{array}{c}\text { Natural Gas } \\
\text { Percentage } \\
\text { of Total US } \\
\text { Commercial } \\
\text { Deliveries } \\
\mathbf{( \% )}\end{array}$ & $\begin{array}{c}\text { Natural Gas } \\
\text { Percentage } \\
\text { of Total US } \\
\text { Industrial } \\
\text { Deliveries } \\
\mathbf{( \% )}\end{array}$ & $\begin{array}{c}\text { Natural Gas } \\
\text { \% of Total } \\
\text { US Vehicle } \\
\text { Fuel } \\
\text { Deliveries } \\
\mathbf{( \% )}\end{array}$ & $\begin{array}{c}\text { Natural Gas } \\
\text { \% of Total } \\
\text { US Electric } \\
\text { Utility } \\
\text { Deliveries } \\
\mathbf{( \% )}\end{array}$ \\
\hline Illinois & $\mathbf{9 . 1 1 6 *}$ & 6.909 & 3.773 & 1.388 & 0.686 \\
\hline
\end{tabular}




\begin{tabular}{|l|c|c|c|c|c|}
\hline Texas & 3.805 & 5.263 & 19.84 & 7.915 & 23.523* \\
\hline Wyoming & $\mathbf{0 . 2 6 7 *}$ & 0.335 & 0.651 & 0.122 & 0.013 \\
\hline
\end{tabular}

TABLE 10 - Percentage of US Natural Gas Deliveries in 2006, by Sector and State

$*$ indicates value used for analysis.

As can be seen in the above table, Texas dominates US Natural Gas usage, specifically in the Electric and Industrial sectors. Wyoming, a sparsely populated state, is not a large consumer of Natural Gas. The usage of Natural Gas in each state does not reflect an accurate picture of the market, as Natural Gas can travel long distances from a point of origin, and in added and withdrawn from pipelines by local demand, not unlike electricity (Figure 3). We then assume that what is of import is the potential for a state to reach the market at a National scale.

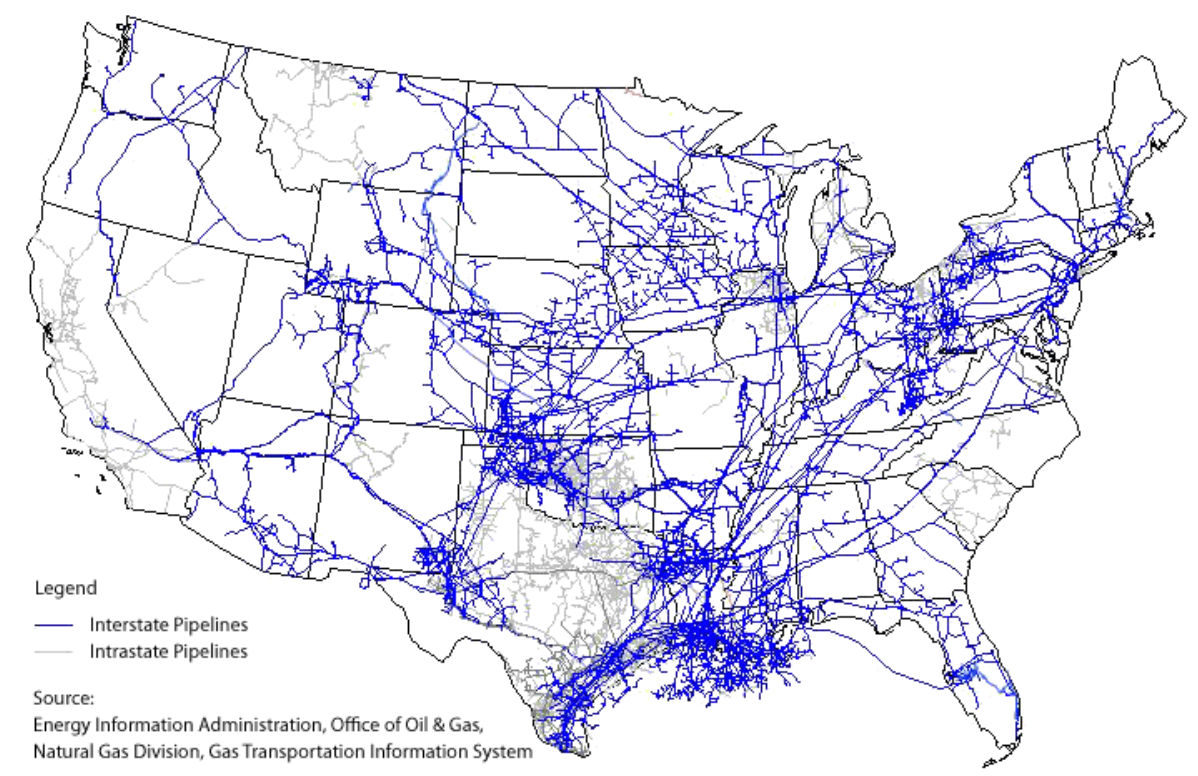

Figure 3:The National Natural Gas Network. Source: EIA.

In EIA's NEMS model, the Natural Gas Transmission and Distribution Module forecasts demand, supply and transmission for each region in the country. The North American market is divided up into 19 segments, based on the 9 US Census division and incorporating Canada and Mexico (Figure 4). 


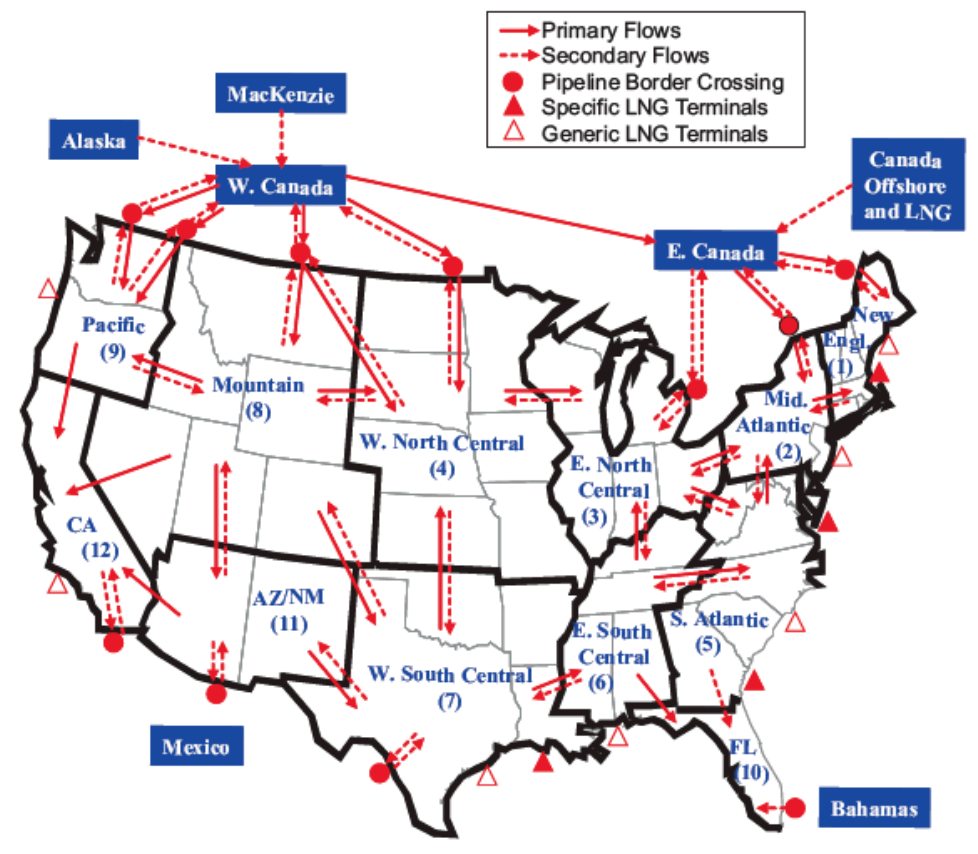

Figure 4. Natural Gas Transmission and Distribution Module (NGTDM) Network. Source: EIA

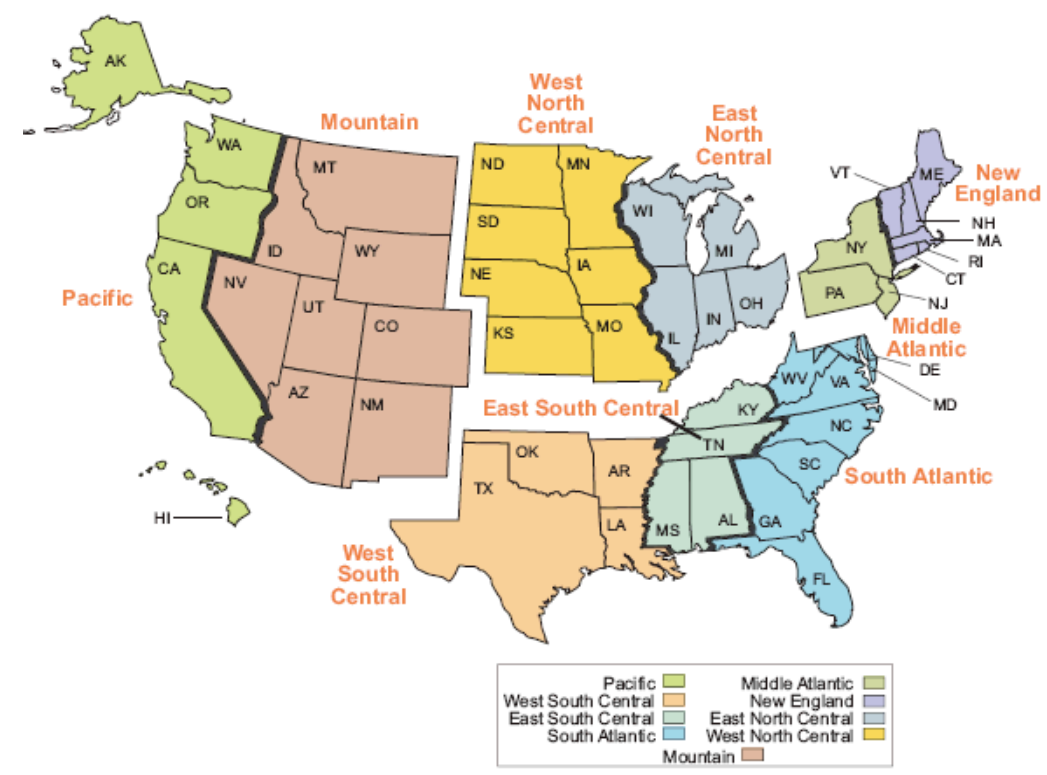

Figure 5. US Census Divisions

EIA forecasts Natural Gas consumption and prices by US Census Divisions (Figure 5). Their forecasts show that Natural Gas Consumption will gradually increase a few percent a year (Table 11)

$\begin{array}{cccc} & 2008 & 2013 & 2028 \\ \text { New England } & 0.90 & 0.96 & 1.14 \\ \text { Middle Atlantic } & 2.26 & 2.43 & 2.47 \\ \text { East North Central } & 3.91 & 4.09 & 4.30 \\ \text { West North Central } & 1.35 & 1.46 & 1.59\end{array}$




$\begin{array}{cccc}\text { South Atlantic } & 2.15 & 2.34 & 2.80 \\ \text { East South Central } & 1.15 & 1.33 & 1.27 \\ \text { West South Central } & 5.58 & 5.88 & 6.33 \\ \text { Mountain } & 1.54 & 1.59 & 1.43 \\ \text { Pacific } & 2.86 & 3.01 & 3.05 \\ \text { Total } & 21.70 & 23.09 & 24.38\end{array}$

Table 11. Natural Gas Consumption by End-Use Sector and Census Division (trillion cubic feet)

EIA also models the flow of Natural Gas through the entire network. The forecasts of the internode volume are not reported. EIA illustrates the topology of the Natural Gas Network in Figure 6. From this diagram, the extent of each region's influence can be determined.

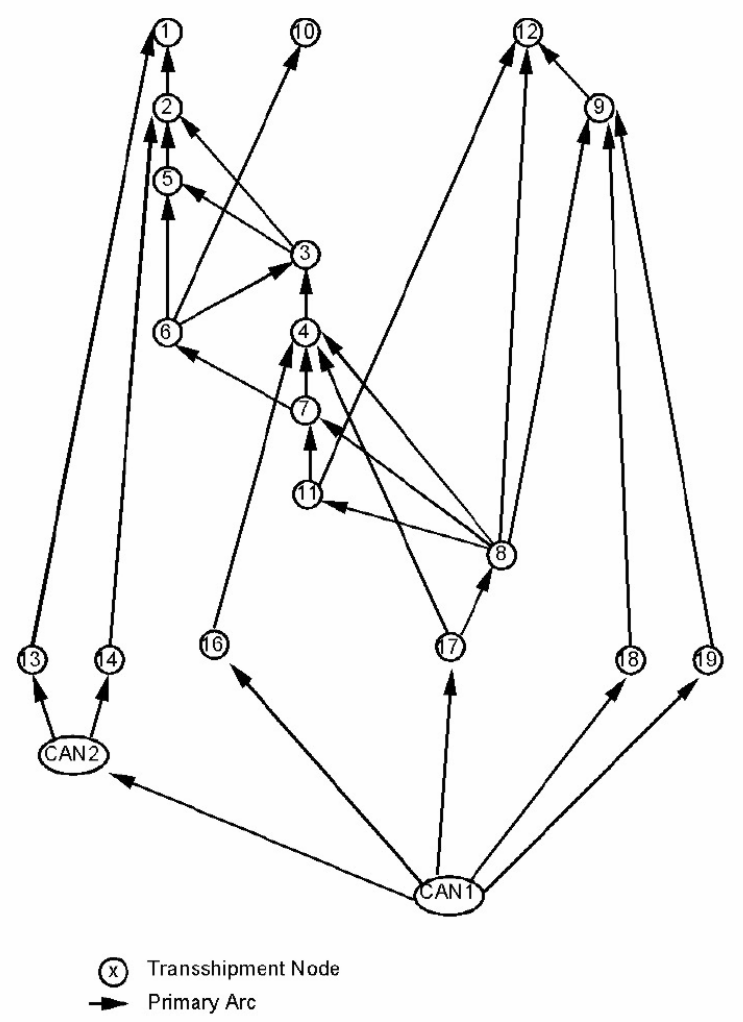

Figure 6: Network "Tree" or Hierarchical, Acyclic Network of Primary Arcs. Source: EIA.

From the Network topology the extent of each of the three States of interest (rather their Census Region) can be determined:

1. Wyoming (NGDTM region 8) or Mountain region ships gas to the entire US network (NGDTM regions 1-7, 9-12).

2. Illinois (NGDTM region 3) or East North Central ships gas to the Atlantic states excluding Florida (NGDTM regions 1, 2 and 5).

3. Texas (NGDTM region 7) or West South Central ships gas to the Central and Eastern States (NGDTM regions $1-6$, and 10 ). 
Accounting for the breadth of the market, the aggregated consumption of the regions can be calculated (Table 12):

\begin{tabular}{lrrrrrr}
\multicolumn{3}{c}{ Total Aggregated Consumption } \\
& (trillion cubic feet) & \multicolumn{4}{c}{ Percent of National Market } \\
& 2008 & 2013 & 2028 & 2008 & 2013 & 2028 \\
Illinois & 9.22 & 9.82 & 10.71 & $42.5 \%$ & $42.5 \%$ & $43.9 \%$ \\
Texas & 17.29 & 18.49 & 19.90 & $79.7 \%$ & $80.1 \%$ & $81.6 \%$ \\
Wyoming & 21.70 & 23.09 & 24.38 & $100.0 \%$ & $100.0 \%$ & $100.0 \%$
\end{tabular}

Table 12. Forecast aggregated consumption from States (in respective Census Region)

In Stage II the individual State's contribution or influence in the Natural Gas distribution network can be estimated, accounting for the nature of the current and planned pipeline infrastructure in each state.

Using the aggregated consumption as proxy for the size of the market, the relative size of the market for each State can be estimated for the suitability analysis as the following (Table 13):

\begin{tabular}{|l|c|c|}
\hline & $\begin{array}{c}\text { UOA } \\
\text { ranking }\end{array}$ & UOA ranking \\
\hline Region & $\mathbf{2 0 1 3}$ & $\mathbf{2 0 2 8}$ \\
\hline Illinois & 3 & 3 \\
\hline Texas & 4 & 4 \\
\hline Wyoming & 5 & 5 \\
\hline \multicolumn{2}{|c|}{ Table 13. State ranking for Natural Gas }
\end{tabular}

Product: Synthetic Natural Gas

Market: National Natural Gas Market Ability

Future Prices: Natural Gas National Price

Distribution Method of Interest: Pipeline

\section{4) Hydrogen}

Currently Hydrogen is used for industrial and chemical purposes. In the future, Hydrogen gas, either through fuel cells or combustion, will be used for transportation due to its ability to "burn clean" at the tailpipe, and the potential for low- or zero-carbon generation methods. We will be examining the use of Hydrogen for transportation demand for use in this study. The method of Hydrogen production we focus on here is centralized, as opposed to distributed or forecourt, due to the in situ production of Hydrogen in the field.

\section{H2 Gas Distribution}

The optimal methodology for distributing Hydrogen Gas, assuming it is to be used as a transport fuel, depends on the volume of $\mathrm{H}_{2}$ flowing from the source and the proximity of the $\mathrm{H}_{2}$ demand (Yang and Ogden 2007). The figure below shows a tradeoff surface of $\mathrm{H}_{2}$ distribution methodology. 


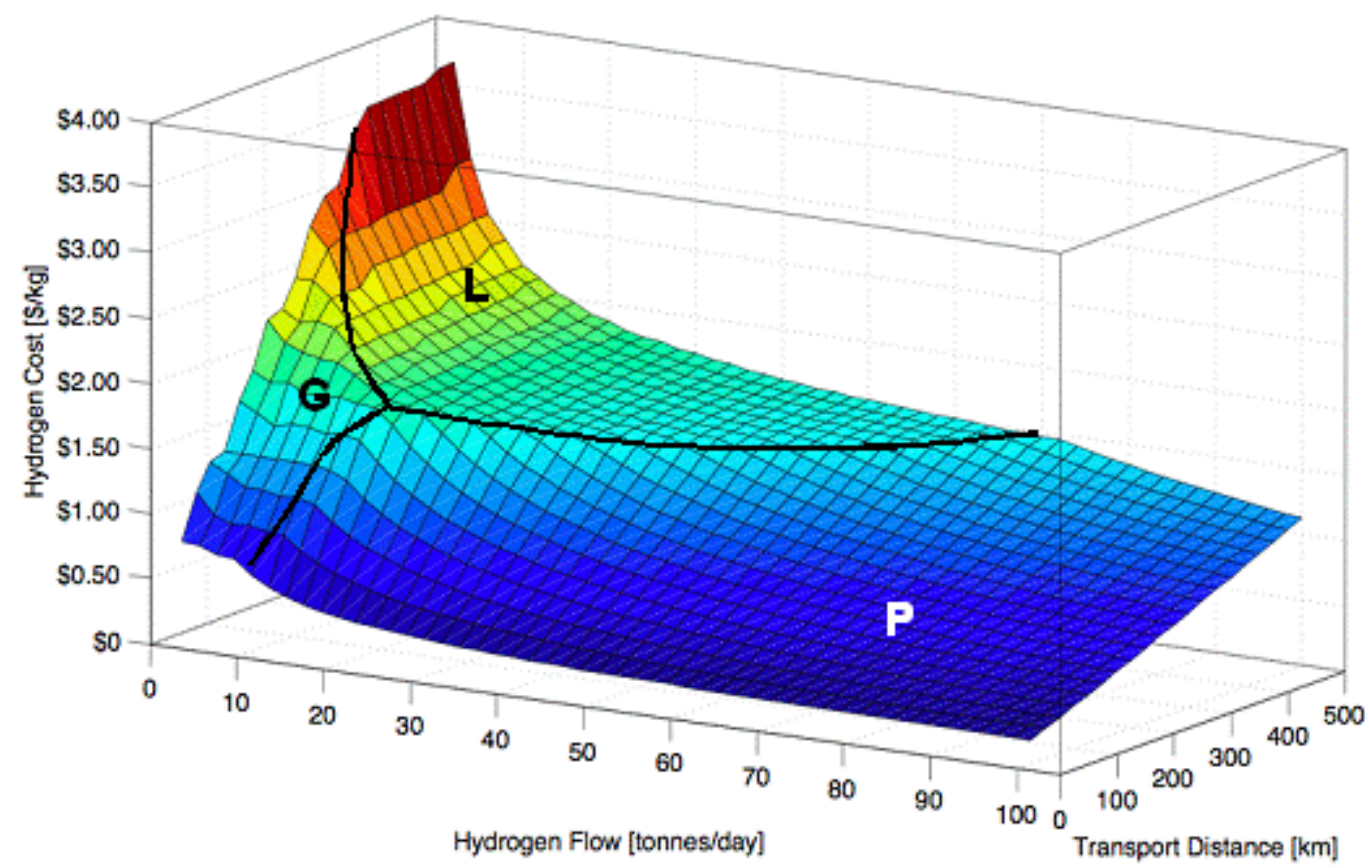

Figure 7.Minimum hydrogen transmission costs as a function of $\mathrm{H} 2$ flow and transport distance. $\mathrm{G}=$ Compressed Gas Trucks, L = Liquid Gas Trucks, P = Pipeline. From Yang and Ogden (2007).

We can make some coarse cutoffs representing this function. The Compressed Gas option above can be ruled infeasible. For the Stage I analysis, we assume high flow of $\mathrm{H}_{2}$, indicating the transportation only due to pipeline. For modeling distribution to nearby industrial purposes we can assume the use of trucks.

For the size of the future Hydrogen Market, we will take advantage of previous analysis by Singh et al (2005), who projected Hydrogen demand and cost at the US Census region (see Figure 7, above) level. The analysis forecasted at decadal timesteps, forcing our analysis to conform accordingly; we will use the 2010 and 2030 values for 2013 and 2028, respectively (tables 14 and 15).

\begin{tabular}{|c|c|c|c|}
\hline & & \multicolumn{2}{|c|}{ Total Quads (from all sources) } \\
\hline Region & State & 2010 & 2030 \\
\hline East North Central & Illinois & .00002 & 0.33 \\
\hline West South Central & Texas & .00001 & 0.25 \\
\hline Mountain & Wyomin & .00001 & 0.14 \\
\hline
\end{tabular}

Table 14. Size of Hydrogen market in Quads. From Table 3.9 (Singh et al, 2005)

\begin{tabular}{|c|c|c|c|}
\hline & & \multicolumn{2}{|c|}{ Total Hydrogen Costs (\$/ GEG) } \\
\hline Region & State & 2010 & 2030 \\
\hline East North Central & Illinois & 4.54 & 2.73 \\
\hline West South Central & Texas & 4.60 & 2.93 \\
\hline Mountain & Wyoming & 4.99 & 4.58 \\
\hline
\end{tabular}

Table 15. Centralized Production, Delivery, and Dispensing of H2 Using Coal with Carbon Sequestration. These estimates based on the 2010 delivery method based on Cryogenic Tanker Delivery and the 2030 delivery method being Pipeline Delivery. From Table A.2 (Singh et al, 2005) 
To obtain the size of the market (estimated as the size of the Census Region), the Total Quads are multiplied by the Hydrogen costs, and the conversion factor (8.77 x 10^9 GEG/Quad)(Table 16).

\begin{tabular}{|l|c|c|}
\hline & \multicolumn{2}{|l|}{$\begin{array}{l}\text { Hydrogen Market (US Census Regions) } \\
\text { (\$Million) }\end{array}$} \\
\hline Region & $\mathbf{2 0 1 0}$ & $\mathbf{2 0 3 0}$ \\
\hline East North Central & 0.796 & 7900.893 \\
\hline West South Central & 0.403 & 6424.025 \\
\hline Mountain & 0.438 & 5623.324 \\
\hline
\end{tabular}

Table 16. Size of future Hydrogen market in Dollars

These estimates could be scaled down to assess the proportion of the Hydrogen demand in each State, but due to the uncertainty of the roll-out of the Hydrogen market, and more importantly, the potential for Hydrogen to be transported inter-states, we will use the Census region estimates as proxies.

The approximate size of the Hydrogen market was calculated by state and is as follows (Table 17):

\begin{tabular}{|c|c|c|}
\hline & $\begin{array}{c}\text { UOA } \\
\text { ranking }\end{array}$ & UOA ranking \\
\hline Region & $\mathbf{2 0 1 3}$ & $\mathbf{2 0 2 8}$ \\
\hline Illinois & 1 & $\mathbf{5}$ \\
\hline Texas & 1 & $\mathbf{4}$ \\
\hline Wyoming & 1 & $\mathbf{4}$ \\
\hline
\end{tabular}

Table 17. Rankings of Hydrogen market

Product: Hydrogen Gas

Market: Hydrogen Gas for transportation

Future Prices: Hydrogen Gas by Census Region

Distribution Method of Interest: Pipeline, Trucking

\section{The Hazards Resource Assumptions and Methodology}

Capturing the impact and scale of potential Hazards is a long-standing component of site suitability analysis. There are a number of ways to capture Hazards, in the economic, social, environmental domains. We capture a few of these in Stage I, and can incorporate feedback from BP to expand this section. Currently we use the following objectives for siting a UCG operation:

1) No construction on or very near water bodies, including rivers.

2) No construction on or near park or public land

3) No construction on or near developed or populated land

4) No construction where there is a major transportation through-fare

5) A greater preference to regions with fewer geologic faults

6) A preference for regions with high Oil Well Density

\section{GIS Methodology}

For this site suitability analysis, we use a screening and ranking procedure to promote or exclude regions based on their constituents according to the topic areas:

1. Geologic Resource

2. Infrastructure 


\title{
3. Market
}

4. Hazards

We performed all geospatial analyses at a fine scale $(\sim 30 \mathrm{~m})$, then translated or summarized those results to a coarser resolution grid, with approximately a $2 \mathrm{~km} \times 2 \mathrm{~km}$ resolution $(2010 \mathrm{~m} \times 2010 \mathrm{~m})$. This technique provided a balance between fine-grain details and synoptic analyses. The tradeoffs of a fine grain analysis is that there are more analysis units and necessitates a great computational time. A coarser grain analysis unit could potentially "wash out" the details of the analysis, yet is faster to compute and easier to interpret. Following discussions with BP, we can determine a more ideal spatial grain for the analysis in Stage II.

Each UCG product ranking was performed independently, as each has different Infrastructure and Market layers. The Additional Economic Incentives sub-layer (Sequestration and EOR) of the Market layer, the Geologic Resource Layer, and the Hazards layer are identical for all products.

One the layers were calculated, the Geologic Resource layer, the Infrastructure and the Hazards layer were summed and normalized, then weighted by the product-dependent Market layer.

\section{Preliminary Maps and Results}

\author{
INSERT MAPS HERE
}

\section{Conclusions and Future Work}

This preliminary exercise in site suitability analysis for UCG has shown that in Wyoming and

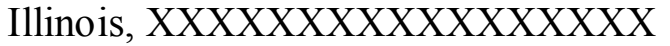

This work has been limited in two domains, data and stakeholder input. Lack of geospatial data of any kind in a spatial site suitability study is a challenge. When the missing data is from a major topic, like geology, where no proxies can be readily created, it can hinder progress. The latter issue, lack of stakeholder input can be remedied through discussion with BP about their decision-making process with regard to each of the major domains of interest. This work can be extended in multiple dimensions. First, the site suitability analysis can be extended to include the entirety of each of the three states. Secondly, all of North America can be analyzed, potentially at a coarser resolution as to be readily interpretable. Third, the methodology and results need to be peer-reviewed either in a formal or informal setting. Lastly, as mentioned above, incorporating stakeholder input would ground the site suitability process and lead to a more refined product, and potentially better guidance as to how BP can proceed with UCG.

An arena for future enhancement of this analysis is in its temporal components. Forecasting the demand, price and location demanded for UCG products is challenging due in part to the inherently coupled nature of the market and in part to the uncertainty of population trends. 


\section{References}

Burton, E. Friedmann, J.S., Upadhye, R., 2006. Best Practices in Underground Coal

Gasification, eed.llnl.gov/co2/pdf/BestPracticesinUCG-draft.pdf

DOE/EIA, 2008, Annual Energy Outlook 2008 (Early Release), Energy Information

Administration, http://www.eia.doe.gov/oiaf/aeo/

EIA, 2006. Estimated Natural Gas Pipeline Mileage in the Lower 48 States.

www.eia.doe.gov/pub/oil_gas/natural_gas/analysis_publications/ngpipeline/mileage.html

EIA, 2007a. Natural Gas Navigator, Energy Information Administration, tonto.eia.doe.gov/dnav/ng/ng_cons_top.asp

EIA, 2007b. Electric Power Annual 2006 - State Data Tables

www.eia.doe.gov/cneaf/electricity/epa/epa_sprdshts.html

EIA, 2007c. State Energy Consumption, Price, and Expenditure Estimates (SEDS)

http://www.eia.doe.gov/emeu/states/_seds_updates.html

EIA, 2008. Regional Overviews and Links to Pipeline Companies.

www.eia.doe.gov/pub/oil_gas/natural_gas/analysis_publications/ngpipeline/ngpipelines_companies. html

Huber, G.P., 1974. Multi-Attribute Utility Models: A Review of Field and Field-Like Studies Management Science, Vol. 20, No. 10, Application Series (Jun., 1974), pp. 1393-1402

Johnson, N., C. Yang, J. Ni, J. Johnson, Z. Lin, and J.M. Ogden, 2005. Optimal Design of a Fossil Fuel-Based Hydrogen Infrastructure with Carbon Capture and Sequestration: Case Study in Ohio. Presented at the National Hydrogen Association (NHA) Annual Hydrogen Conference, entitled "Partnering for the Global Hydrogen Future" Washington, DC March 29 - April 1, 2005, UCDITS-RP-05-16

Katzer, J. 2007. The Future of Coal. Cambridge, MA: MIT.

Keeney, R.L. 1980. Siting Energy Facilities, Academic Press, Inc 413 pp.

McMillen, S., Magaw, R.L., and Carovillano, R.L., 2001, Risk-based Decision-Making for Assessing Petroleum Impacts at Exploration and Production Sites., U.S. Dept. of Energy and Petroleum Environmental Research Forum, Government Printing Office, p. 239.

Singh, M., Moore, J., and Shadis, W., 2005. Hydrogen Demand, Production, and Cost by Region to 2050. Center for Transportation Research, Energy Systems Division, Argonne National Laboratory. www.transportation.anl.gov/pdfs/TA/351.pdf 
U.S. Census Bureau, Population Division, Interim State Population Projections, 2005. Table A1:

Interim Projections of the Total Population for the United States and States: April 1, 2000 to July 1, 2030

www.census.gov/population/www/projections/projectionsagesex.html

Yang, C., J. Ogden, 2007. Determining the lowest-cost hydrogen delivery mode. International Journal of Hydrogen Energy Vol. 32, pp. 268- 286. 


\section{Appendix A: Pseudocode for GIS Analysis}

All products will be evaluated for each of the four Topic Areas differently. All products will use the same Geologic Resource and Hazards layers. Each product will use different layers for Market and Infrastructure.

Overall methodology

1) For each product, state and timestep $(2013,2028)$ add:

Geologic Resource +

Infrastructure +

Hazards

2) Divide by 20 (max of 5, 4 layers)

3) Multiply by Market weightings

4) Round to get integer values

\section{Pseudocode for Geologic Resource:}

For Geologic resource, we will only evaluate areas greater than 1000 feet.

1) Define regions with deep ( $>1000 \mathrm{ft})$ coal seams:

If UOA has any regions with seam_depth $>1000 \mathrm{ft}$, UOA $=5$

Else UOA $=0$

2) Sub-define regions with seams $>3 \mathrm{~m}$ in thickness:

If UOA has any regions with seam_thickness $>4 \mathrm{~m}, \mathrm{UOA}=5$

If UOA has any regions with $2 \mathrm{~m}>$ seam_thickness $<4 \mathrm{~m}, \mathrm{UOA}=4$

Else UOA $=0$

** For Illinois, use the following breakpoints, based on available data:

If UOA has any regions with seam_thickness $>66 \mathrm{in}, \mathrm{UOA}=5$

If UOA has any regions with $42 \mathrm{~m}>$ seam_thickness $<66 \mathrm{in}, \mathrm{UOA}=4$

Else UOA $=0$

3) Resource Density

Attribute sub-regions with number of stacked seams $>3 \mathrm{~m}$ in thickness.

If UOA has any regions with $>5$ stacked seams, $\mathrm{UOA}=5$

If UOA has any regions with $4>$ stacked seams $<5, \mathrm{UOA}=4$

If $\mathrm{UOA}$ has any regions with $1>$ stacked seams $<4, \mathrm{UOA}=3$

If UOA has any regions with 1 stacked seam, $\mathrm{UOA}=2$

Else UOA $=0$

4) Coal Rank:

Since present Data reflects only "Medium and High Bituminous":

If UOA has any regions of "Medium and High Bituminous", UOA $=5$

Else, $\mathrm{UOA}=0$ 
(For Stage II, we can incorporate Texas data, assigning Anthracite a value of 5, Lignite $=$ Val of 1)

5) Water Table

Presently we have no aquifer depth.

For Stage II, we can use the following cutoffs:

If UOA possess any seams below water table, value $=5$, else $=0$

6) Summarize:

Sum UOA grids of Seam depth, Seam Thickness, and number of Seams, Coal Rank

Divide by 4 , and round to integer values

\section{Pseudocode for Infrastructure:}

1) Electricity

Calculate Euclidean distance surface to all Major Electric Substations

Using above distance grid (at native resolution (e.g. $30 \mathrm{~m}$ ) :

If UOA has any cells with distance values of $<5 \mathrm{~km}, \mathrm{UOA}=5$

If UOA has any cells with distance values between $6 \mathrm{~km}$ and $25 \mathrm{~km}, \mathrm{UOA}=4$

If UOA has any cells with distance values between $26 \mathrm{~km}$ and $100 \mathrm{~km}, \mathrm{UOA}=2$

Else $\mathrm{UOA}=0$

2) Liquid Fuels:

We will assume that all Liquid Fuels will move via trucks to its major regions of utility:

Calculate Euclidean distance grid to all major highways (Interstates)

Using above distance grid (at native resolution (e.g. $30 \mathrm{~m}$ ) :

If UOA has any cells with distance values of $<5 \mathrm{~km}, \mathrm{UOA}=5$

If UOA has any cells with distance values between $6 \mathrm{~km}$ and $25 \mathrm{~km}, \mathrm{UOA}=4$

If UOA has any cells with distance values between $26 \mathrm{~km}$ and $100 \mathrm{~km}, \mathrm{UOA}=2$

Else $\mathrm{UOA}=0$

3) Natural Gas

The Natural Gas suitability is based on the proximity to current pipelines and Pipeline interconnections. The proximity to pipelines has slightly greater weighting:

Calc Euclidean distance to Natural Gas Pipelines

Using above distance grid (at native resolution (e.g. $30 \mathrm{~m}$ ) :

If UOA has any cells with distance values of $<5 \mathrm{~km}, \mathrm{UOA}=5$

If UOA has any cells with distance values between $6 \mathrm{~km}$ and $25 \mathrm{~km}, \mathrm{UOA}=4$

If UOA has any cells with distance values between $26 \mathrm{~km}$ and $100 \mathrm{~km}, \mathrm{UOA}=2$

Else $\mathrm{UOA}=0$

Calc Euclidean distance to Pipeline Interconnections

Using above distance grid (at native resolution (e.g. $30 \mathrm{~m}$ ) :

If UOA has any cells with distance values of $<10 \mathrm{~km}, \mathrm{UOA}=5$ 
If UOA has any cells with distance values between $11 \mathrm{~km}$ and $50 \mathrm{~km}, \mathrm{UOA}=4$

If UOA has any cells with distance values between $51 \mathrm{~km}$ and $100 \mathrm{~km}, \mathrm{UOA}=2$

Else $\mathrm{UOA}=0$

Summarize for Natural Gas:

Perform MAX function on Gas Pipeline and Pipeline Interconnections on UOAs

4) Hydrogen

The Infrastructure for hydrogen is either based on trucking to industrial plants (for Stage I, we are using Fertilizer plants as a proxy for the Industrial Plants. We will assume that new $\mathrm{H} 2$ pipelines will travel along the same right-of-ways as current pipelines. For Stage II, we can implement more precise SIC codes), or piping it (through new pipelines) to city gates for transportation. The transportation use has a higher weighting:

Calculate Euclidean distance grid to all major highways Using above distance grid (at native resolution (e.g. 30m):

If UOA has any cells with distance values of $<5 \mathrm{~km}, \mathrm{UOA}=5$

If UOA has any cells with distance values between $6 \mathrm{~km}$ and $25 \mathrm{~km}, \mathrm{UOA}=4$

If UOA has any cells with distance values between $26 \mathrm{~km}$ and $100 \mathrm{~km}, \mathrm{UOA}=2$

Else $\mathrm{UOA}=0$

Calc Euclidean distance to Current Gas Pipelines

Using above distance grid (at native resolution (e.g. 30m):

If UOA has any cells with distance values of $<5 \mathrm{~km}, \mathrm{UOA}=5$

If UOA has any cells with distance values between $6 \mathrm{~km}$ and $25 \mathrm{~km}, \mathrm{UOA}=4$

If UOA has any cells with distance values between $26 \mathrm{~km}$ and $100 \mathrm{~km}, \mathrm{UOA}=2$

Else $\mathrm{UOA}=0$

Summarize for Hydrogen:

Perform MAX function on Highways and Pipeline UOAs

\section{Pseudocode for Market}

For each UCG product, the Market layer has three components; the location of the access to the demand centers (and not necessarily the demand centers themselves), the relative economic rank of each market, and the sequestration potential. Each product's Market layer will be calculated separately, and then multiplied by the Sequestration Potential Layer.

Additional Economic Incentives Layer

a) Multiple Source Sequestration

The potential for sequestration is derived from a National Map of Sequestration

If UOA has any area in the Sequestration Map, it receives a 1. Else, it receives a 0.5.

b) Oil \& Gas Field Layer (for secondary \& tertiary recovery)

If UOA has any cells (or area) that is also an Oil Field, it receives a 1.1. Else, it receives a 0.5.

c) Sequestration Synthesis 
Perform a MAX function on the Multiple Source Sequestration and the Oil \& Gas Field Layer UOAs.

1) Electricity

Calculate Euclidean distance surface to all Electric Substations

Using above distance grid (at native resolution (e.g. $30 \mathrm{~m}$ ) :

If UOA has any cells with distance values of $<5 \mathrm{~km}, \mathrm{UOA}=5$

If UOA has any cells with distance values between $6 \mathrm{~km}$ and $25 \mathrm{~km}, \mathrm{UOA}=4$

If UOA has any cells with distance values between $26 \mathrm{~km}$ and $100 \mathrm{~km}, \mathrm{UOA}=2$

Else $\mathrm{UOA}=0$

Multiply by the Statewide Ranking in the table below

\begin{tabular}{|c|c|c|c|}
\hline & \multicolumn{2}{|c|}{$\begin{array}{c}\text { Size of Electricity Market } \\
\text { (relative to entire US) } \\
\text { (\$Billion) }\end{array}$} & $\begin{array}{c}\text { Statewide UOA } \\
\text { Ranking }\end{array}$ \\
\hline State & 2013 & 2028 & $2013 \& 2028$ \\
\hline Illinois & 1.48 & 1.92 & 4 \\
\hline Texas & 3.56 & 4.63 & 5 \\
\hline Wyoming & 0.16 & 0.20 & 3 \\
\hline
\end{tabular}

Divide by 5, and Round.

Multiply by Sequestration Layer and Round

\section{2) Liquid Fuels}

Since we are evaluating 2 separate liquid fuels, the maximum suitability calculated for either Jet

Fuel or Diesel will be the value used for the analysis.

a) Jet Fuel:

Determine location of large Civilian airports and Military bases with airports in each state, and states within 200 miles. The relaxed distance ranking for Military airports show an expanded benefit for locations in proximity to Military stations with airports.

Calculate Euclidean distance grid to all major Civilian airports international operations. This includes co-located National Guard operations.

Using above distance grid (at native resolution (e.g. $30 \mathrm{~m}$ ) :

If UOA has any cells with distance values of $<5 \mathrm{~km}, \mathrm{UOA}=5$

If UOA has any cells with distance values between $6 \mathrm{~km}$ and $25 \mathrm{~km}, \mathrm{UOA}=4$

If UOA has any cells with distance values between $26 \mathrm{~km}$ and $100 \mathrm{~km}, \mathrm{UOA}=2$

Else UOA $=0$

Calculate Euclidean distance grid to all Military airports

Using above distance grid (at native resolution (e.g. 30m) :

If UOA has any cells with distance values of $<10 \mathrm{~km}, \mathrm{UOA}=5$

If UOA has any cells with distance values between $11 \mathrm{~km}$ and $50 \mathrm{~km}, \mathrm{UOA}=4$

If UOA has any cells with distance values between $51 \mathrm{~km}$ and $100 \mathrm{~km}, \mathrm{UOA}=2$

Else $\mathrm{UOA}=0$

Perform MAX function on Jet Fuels, Commercial and Military UOAs 
b)Diesel:

The Diesel market is mostly trucking, with some Railroad utility.

Calculate Euclidean distance grid to all gas stations:

Preferably those selling Diesel and only large stations (like truck stops)

Using above distance grid (at native resolution (e.g. $30 \mathrm{~m}$ ):

If UOA has any cells with distance values of $<5 \mathrm{~km}, \mathrm{UOA}=5$

If UOA has any cells with distance values between $6 \mathrm{~km}$ and $25 \mathrm{~km}, \mathrm{UOA}=4$

If UOA has any cells with distance values between $26 \mathrm{~km}$ and $100 \mathrm{~km}, \mathrm{UOA}=2$

Else $\mathrm{UOA}=0$

Calculate Euclidean distance grid to railroad yards and hubs

Using above distance grid (at native resolution (e.g. $30 \mathrm{~m}$ ):

If UOA has any cells with distance values of $<5 \mathrm{~km}, \mathrm{UOA}=5$

If UOA has any cells with distance values between $6 \mathrm{~km}$ and $25 \mathrm{~km}, \mathrm{UOA}=4$

If UOA has any cells with distance values between $26 \mathrm{~km}$ and $100 \mathrm{~km}, \mathrm{UOA}=2$

Else $\mathrm{UOA}=0$

Multiply by the following Statewide Ranking:

\begin{tabular}{|c|c|c|c|}
\hline & \multicolumn{2}{|c|}{$\begin{array}{c}\text { Size of Local Diesel Market } \\
\text { (relative to entire US) (\$Billion) }\end{array}$} & $\begin{array}{c}\text { Statewide UOA } \\
\text { Ranking }\end{array}$ \\
\hline State & $\mathbf{2 0 1 3}$ & $\mathbf{2 0 2 8}$ & $\mathbf{2 0 1 3 ~ \& ~ 2 0 2 8}$ \\
\hline Illinois & 3.88 & 5.19 & $\mathbf{4}$ \\
\hline Texas & 10.32 & 13.81 & $\mathbf{5}$ \\
\hline Wyoming & 1.14 & 1.53 & $\mathbf{3}$ \\
\hline
\end{tabular}

Divide by 5 , and Round.

Perform MAX function Diesel Highway and Diesel Railroad UOAs

Summarize for Liquid Fuels:

Perform MAX function Jet Fuels and Diesel Fuels UOAs

Divide by 5 , and Round.

Multiply by Sequestration Layer and Round

3) Natural Gas

Calc Euclidean distance to Pipeline Interconnections

Using above distance grid (at native resolution (e.g. $30 \mathrm{~m}$ ) :

If UOA has any cells with distance values of $<5 \mathrm{~km}, \mathrm{UOA}=5$

If UOA has any cells with distance values between $6 \mathrm{~km}$ and $25 \mathrm{~km}, \mathrm{UOA}=4$

If UOA has any cells with distance values between $26 \mathrm{~km}$ and $100 \mathrm{~km}, \mathrm{UOA}=2$

Else $\mathrm{UOA}=0$

Multiply by the following Statewide ranking: 


\begin{tabular}{|c|c|}
\hline Natural Gas & $\begin{array}{c}\text { Statewide UOA } \\
\text { Ranking }\end{array}$ \\
\hline State & $\mathbf{2 0 1 3}$ \& 2028 \\
\hline Illinois & $\mathbf{3}$ \\
\hline Texas & $\mathbf{4}$ \\
\hline Wyoming & $\mathbf{5}$ \\
\hline
\end{tabular}

Divide by 5, and Round.

Multiply by Sequestration Layer and Round

4) Hydrogen

Calc Euclidean distance to Industrial Locations

Using above distance grid (at native resolution (e.g. 30m):

If UOA has any cells with distance values of $<5 \mathrm{~km}, \mathrm{UOA}=4$

If UOA has any cells with distance values between $6 \mathrm{~km}$ and $25 \mathrm{~km}, \mathrm{UOA}=3$

If UOA has any cells with distance values between $26 \mathrm{~km}$ and $100 \mathrm{~km}, \mathrm{UOA}=2$

Else $\mathrm{UOA}=0$

Calc Euclidean distance to City Gates (or City Centroid)

If UOA has any cells with distance values of $<5 \mathrm{~km}, \mathrm{UOA}=5$

If UOA has any cells with distance values between $6 \mathrm{~km}$ and $25 \mathrm{~km}, \mathrm{UOA}=4$

If UOA has any cells with distance values between $26 \mathrm{~km}$ and $100 \mathrm{~km}, \mathrm{UOA}=2$

Else $\mathrm{UOA}=0$

Perform MAX function Industrial Locations and City Gates UOAs.

Multiply by the following Statewide Ranking:

\begin{tabular}{|l|c|c|}
\hline & $\begin{array}{c}\text { UOA } \\
\text { ranking }\end{array}$ & UOA ranking \\
\hline Region & $\mathbf{2 0 1 3}$ & $\mathbf{2 0 2 8}$ \\
\hline Illinois & 1 & $\mathbf{5}$ \\
\hline Texas & 1 & $\mathbf{4}$ \\
\hline Wyoming & 1 & $\mathbf{4}$ \\
\hline
\end{tabular}

For the 2028 analysis, divide by 5 and round.

Multiply by Sequestration Layer and Round

\section{Pseudocode for Hazards}

1) Existing water bodies

If $\mathrm{UOA}<25 \%$ water body, $\mathrm{UOA}=5$

If $\mathrm{UOA}$ is between $25 \%$ and $50 \%$ water, $\mathrm{UOA}=3$

Else $\mathrm{UOA}=0$

2) Existing park or recreation area, excluded land use. 
If $\mathrm{UOA}<25 \%$ park, $\mathrm{UOA}=5$

If $\mathrm{UOA}$ is between $25 \%$ and $50 \%$ water, $\mathrm{UOA}=1$

Else $\mathrm{UOA}=0$

3) Existing development; such as prison, commercial, residential, military.

Residential defined as Metropolitan Statistical Area (MSA), as defined by the US Census.

If $\mathrm{UOA}<25 \%$ developed, $\mathrm{UOA}=5$

If UOA is between $25 \%$ and $50 \%$ developed, $\mathrm{UOA}=3$

Else $\mathrm{UOA}=0$

4) Transportation corridor

Calculate Euclidean distance grid to all major highways

Using above distance grid (at native resolution (e.g. 30m):

If UOA has any cells with distance values of $<10 \mathrm{~km}, \mathrm{UOA}=1$

If UOA has any cells with distance values between $10 \mathrm{~km}$ and $100 \mathrm{~km}, \mathrm{UOA}=3$

Else $\mathrm{UOA}=5$

5) Earthquake Faults prevalence

If UOA has no faults, UOA $=5$

If UOA has between 1-2 faults, $\mathrm{UOA}=4$

Else UOA $=1$

6) Oil Well Density

If UOA has $<5$ Oil Wells UOA $=5$

If UOA has 6 to 25 Wells, $\mathrm{UOA}=4$

If UOA has 26 to 100 Wells, $\mathrm{UOA}=3$

Else $\mathrm{UOA}=2$

Hazard Summary:

Perform a MIN function on Water bodies, Park Lands, Development, Transportation, Earthquake

Faults, and Oil Wells UOAs.

\section{Creating the Ranking Layers}

For each product, timestep and state:

1. Sum Geologic Resource, Infrastructure, Hazards UOA layers.

2. Divide by 3

3. Multiply by Market layer.

4. Round to get integer values.

Sum all four products layer (per state and timestep) and divide by 4 Round to get integer values. 


\section{Appendix B: Dataset Sources and Coarse Metadata}

\begin{tabular}{|c|c|c|c|}
\hline Database Name & Source & Date & Access Constraints \\
\hline $\begin{array}{l}\text { Abandoned } \\
\text { Mines }\end{array}$ & USGS & 1998 & Public Use \\
\hline $\begin{array}{l}\text { Active Mines and } \\
\text { mineral plants }\end{array}$ & USGS & 2003 & Public Use \\
\hline Airports & $\begin{array}{l}\text { Bureau of Transportation } \\
\text { Statistics }\end{array}$ & 2007 & Public Use \\
\hline Aquifers & National Atlas of the US & Oct-03 & Public Use \\
\hline City Civil Areas & $\begin{array}{l}\text { Navteq Points of Interest } \\
\text { 1Q2007 }\end{array}$ & Nov-06 & Federal Government HLS/HD Use only \\
\hline Coal Fields & USGS & Aug-01 & Public Use \\
\hline $\begin{array}{l}\text { Electric Power } \\
\text { Plants }\end{array}$ & Global Energy Decisions & Mar-07 & $\begin{array}{l}\text { Federal Government HLS/HD Use only (See } \\
\text { metadata) }\end{array}$ \\
\hline $\begin{array}{l}\text { Electric } \\
\text { Transmission } \\
\text { Lines }\end{array}$ & Global Energy Decisions & Mar-07 & $\begin{array}{l}\text { Federal Government HLS/HD Use only (See } \\
\text { metadata) }\end{array}$ \\
\hline Faults & National Atlas of the US & Jan-05 & Public Use \\
\hline Federal Lands & National Atlas of the US & Dec-05 & Public Use \\
\hline Fertilizer Plants & $\begin{array}{l}\text { InfoUSA (Extracted by SIC } \\
\text { code 287301) }\end{array}$ & 2003 & Public Use \\
\hline $\begin{array}{l}\text { Gas and Oil } \\
\text { Pipelines }\end{array}$ & PennWell MAP search & Mar-07 & $\begin{array}{l}\text { Federal Government HLS/HD Use only (See } \\
\text { metadata) }\end{array}$ \\
\hline $\begin{array}{l}\text { Gas and Oil } \\
\text { Wells }\end{array}$ & $\begin{array}{l}\text { Techni Graphic Systems, } \\
\text { INC., MMS, USGS, State } \\
\text { Entities }\end{array}$ & Oct-04 & $\begin{array}{l}\text { US Federal Government Agencies, State and } \\
\text { Local Agencies in emergencies; not for public } \\
\text { distribution. }\end{array}$ \\
\hline Lakes & $\begin{array}{l}\text { Navteq Points of Interest } \\
1 \mathrm{Q} 2007\end{array}$ & Mar-07 & Federal Government HLS/HD Use only \\
\hline Landuse & $\begin{array}{l}\text { Navteq Points of Interest } \\
1 \mathrm{Q} 2008\end{array}$ & Nov-06 & Federal Government HLS/HD Use only \\
\hline $\begin{array}{l}\text { Natural Gas } \\
\text { Delivery Points }\end{array}$ & $\begin{array}{l}\text { Energy Information } \\
\text { Administration }\end{array}$ & Mar-01 & Federal Government Use only \\
\hline $\begin{array}{l}\text { Natural Gas } \\
\text { Power Plants }\end{array}$ & $\begin{array}{l}\text { Energy Information } \\
\text { Administration }\end{array}$ & Mar-01 & Federal Government Use only \\
\hline $\begin{array}{l}\text { Pipeline } \\
\text { Interconnections }\end{array}$ & PennWell MAP search & Mar-07 & Federal Government HLS/HD Use only \\
\hline Populated Places & USGS GNIS & Mar-04 & Public Use \\
\hline Railroads & $\begin{array}{l}\text { Techni Graphic Systems, } \\
\text { Inc., BTS and US Census }\end{array}$ & Jun-04 & $\begin{array}{l}\text { US Federal Government Agencies, State and } \\
\text { Local Agencies in emergencies; not for public } \\
\text { distribution. }\end{array}$ \\
\hline Railroad Yards & $\begin{array}{l}\text { Department of } \\
\text { Transportation (DOT) } \\
\text { Federal Rail Administration } \\
\text { (FRA) }\end{array}$ & Mar-92 & $\begin{array}{l}\text { Government and railroad industry partner } \\
\text { access only }\end{array}$ \\
\hline Roads & Navteq 2Q2006 & May-06 & Federal Government HLS/HD Use only \\
\hline Coal information & $\begin{array}{l}\text { National Coal Resource } \\
\text { Assessment (NCRA) }\end{array}$ & various & Public Use \\
\hline
\end{tabular}

